\title{
Gambaran Kepesertaan Keluarga Berencana (KB) di Provinsi Jawa Timur Tahun 2018
}

\section{Description of Family Planning in the East Java Province, 2018}

\author{
Rizki Arista Devi ${ }^{1}$, Yuly Sulistyorini ${ }^{2}$ \\ Departemen Biostatistika dan Kependudukan ,Fakultas Kesehatan Masyarakat Universitas Airlangga
}

\begin{abstract}
ABSTRAK
Latar Belakang: Jawa Timur merupakan provinsi dengan jumlah penduduk terbesar ke-2 di Indonesia. Laju pertumbuhan penduduk dapat ditekan melalui optimalisasi dan revitalisasi pelaksanaa program Keluarga Berencana (KB) yang saat ini dikelola oleh Badan Kependudukan (BKKBN). Pada penelitian ini akan dijelaskan mengenai gambaran kepesertaan KB di Provinsi Jawa Timur pada Tahun 2018.

Tujuan: Penelitian ini bertujuan untuk mengetahui jenis KB apa saja yang digunakan oleh pasangan usia subur, faktor yang mempengaruhi pemilihan alat kontrasepsi seperti pengetahuan, dan keterpaparan media informasi.

Metode: Metode penelitian dilakukan dengan menggambarkan hasil faktor yang mempengaruhi kepesertaan KB di Provinsi Jawa timur melalui penjelasan data yang diperoleh dari publikasi Survei Kinerja Akuntabilitas Program 2018.

Hasil: Hasil penelitian menunjukkan bahwa faktor yang mempengaruhi kepesertaan KB di Provinsi Jawa Timur Tahun 2018 antara lain pengetahuan. Semakin tinggi pendidikan wanita kawin usia 15-49 tahun di Provinsi Jawa Timur Tahun 2018 menunjukkan semakin banyak terpapar media informasi dibandingkan wanita yang berpendidikan lebih rendah. Wanita yang terpapar media informasi lebih banyak menunjukkan lebih memiliki wawasan yang luas dalam menentukan metode kontrasepsi yang akan digunakannya. Metode kontrasepsi yang paling banyak digunakan oleh wanita kawin usia 15-49 tahun adalah KB suntikan 3 bulan. Peserta KB yang menggunakan KB suntikan 3 bulan lebih dari 50\% di Provinsi Jawa Timur Tahun 2018.

Kesimpulan: Pengetahuan wanita kawin usia 15-49 tahun yang tinggi maka semakin teliti dalam pemilihan metode kontrasepsi yang akan digunakannya. Semakin pengetahuan wanita tersebut baik kemungkinan untuk menggunakan KB lebih besar.
\end{abstract}

Kata Kunci: Keluarga Berencana, Kepesertaan Keluarga Berencana, Provinsi Jawa Timur

\section{ABSTRACT}

Background: East Java is the second most populous province in Indonesia. The rate of population growth can be reduced through the optimization and revitalization of the implementation of the Family Planning (KB) program which is currently managed by the Population Agency (BKKBN). This study will explain the description of family planning in East Java Province in 2018.

Objectives: The purpose of this study was to find out what types of birth control are used by couples of childbearing age, factors that influence the selection of contraceptives such as knowledge, and information media exposure.

Methods: The research method was describing the results of factors affecting family planning participation in East Java Province through explanation publication data Accountability Performance Survey Program 2018. The results showed that factors affecting family planning participation in East Java Province in 2018 included knowledge. The higher women knowledge the more careful in the selection of contraceptive methods to be used. The better the woman's knowledge the possibility to use birth control is greater than women whose knowledge is low. The higher education of married women aged 15-49 years in East Java Province in 2018 shows more exposure to information media compared to women with lower education. Women who are exposed to more information media show more insight into determining which contraceptive method they will use. The most widely used contraceptive method by married women ages 15-49 is 3-month injection birth control. Woman who use 3-month injection are more than 50\% in East Java Province in 2018. 
Conclusion: High knowledge of married women aged 15-49 years, the more careful in the selection of contraception methods. The good knowledge a woman has, the greater possibility for using KB.

Keywords: Family Planning, Family Planning Membership, East Java Province

*Koresponden:

rizki.arista.devi-2017@fkm.unair.ac.id

Rizki Arista Devi

Departemen Biostatistika dan Kependudukan, Fakultas Kesehatan Masyarakat, Universitas Airlangga Jl. Mulyorejo Kampus C Unair Surabaya 601115

\section{PENDAHULUAN}

Jawa Timur merupakan provinsi dengan jumlah penduduk terbesar ke-2 di Indonesia setelah Jawa Barat. Berdasarkan proyeksi penduduk tahun 2017 jumlah penduduk di Jawa Timur sebanyak 39.292.972 jiwa serta laju pertumbuhan penduduk di bawah $1 \%$ per tahun dengan kata lain angka tersebut lebih rendah dibandingkan tingkat rata-rata laju pertumbuhan penduduk di Indonesia sebesar 1,49\% per tahun. Laju pertumbuhan penduduk dapat ditekan melalui optimalisasi dan revitalisasi pelaksanaa program Keluarga Berencana (KB) yang saat ini dikelola oleh Badan Kependudukan dan Keluarga Berencana Nasional (BKKBN).

Program KB dilakukan dengan penggunaan berbagai jenis alat kontrasepsi untuk Pasangan Usia Subur (PUS). Pemerintah saat ini mulai gencar menggalakkan program KB dengan sasaran Pasangan Usia Subur (PUS) pada usia 15-49 tahun. Kelompok Usia perempuan subur ini merupakan peluang perempuan untuk bisa hamil dan melahirkan anak.

Berdasarkan survei RPJMN 2018, Pemakaian kontrasepsi untuk semua cara di antara wanita kawin di Indonesia turun dari 60,9 persen di tahun 2016 menjadi 59,7 persen di tahun 2017 dan pada hasil Survei Kinerja Akuntabilitas Program (SKAP) 2018 naik menjadi 60 persen. Pemakaian kontrasepsi modern di antara wanita kawin 15-49 tahun sebesar 57 persen dan belum mencapai target nasional yang ditetapkan Renstra 2015-2019, tahun 2018 yaitu sebesar 61,1 persen. Pemakaian kontrasepsi modern tertinggi di Provinsi Bangka Belitung dan Bengkulu 65 persen, sementara Provinsi Papua mencapai angka prevalensi pemakaian KB modern terendah yaitu $27 \%$. Pemakaian suatu cara KB tertinggi di Provinsi Bangka Belitung 69 persen, sedangkan terendah di Papua 28 persen (BKKBN, 2018).

Peningkatan pemakaian kontrasepsi (CPR) modern merupakan salah satu dari lima sasaran strategis yang ingin dicapai dari Perwakilan BKKBN Provinsi Jawa Timur. Keempat sasaran strategis lainnya yaitu penurunan unmet need, penurunan angka kelahiran total (TFR) WUS usia 15-49 tahun, peningkatan jumlah peserta KB aktif metode Kontrasepsi Jangka Panjang (MKJP) dan penurunan tingkat putus pakai kontrasepsi. Berdasarkan renstra BKKBN 2015-2019 menargetkan peningkatan pemakaian kontrasepsi (CPR) 57,90 pada tahun 2014 menjadi 61,30 pada tahun 2019.

Pada penelitian ini akan dijelaskan mengenai gambaran kepesertaan KB di Provinsi Jawa Timur pada Tahun 2018. Hal ini dilakukan dengan tujuan untuk mengetahui jenis KB apa saja yang digunakan oleh pasangan usia subur, faktor yang mempengaruhi pemilihan alat kontrasepsi seperti pengetahuan, dan keterpaparan media informasi.

Gambaran kepesertaan KB dapat digunakan sebagai data awal perencanaan pengadaan alat kontrasepsi dan minat pasangan usia subur terhadap metode kontrasepsi tertentu yang paling dominan diminati.

\section{METODE}

Penelitian ini adalah penelitian deskriptif yang berarti penelitian ini akan menggambarkan hasil analisis kepesertaan keluarga berencana (KB) di Jawa Timur tahun 2018. Penelitian dilakukan dengan tahap awal melakukan pengumpulan data. Teknik pengumpulan data yang dilakukan yaitu dengan cara wawancara, observasi, dan mencatat maupun mempelajari dokumen laporan Hasil Analaisis dan Evaluasi Program KKBPK perwakilan BKKBN Provinsi Jawa Timur 2018 pada bulan Januari - Desember 2018. Pengumpulan data dilakukan pada saat kegiatan magang di perwakilan BKKBN Provinsi Jawa Timur.

Data diperoleh dari bidang Advokasi, Penggerakan, dan Informasi (ADPIN), perwakilan BKKBN Provinsi Jawa Timur merupakan data publikasi sehingga dapat di akses oleh pengguna data dan mahasiswa magang. Data sekunder ini adalah data tahunan kepesertaan KB provinsi Jawa Timur 2018. Responden pada penelitian survei tersebut adalah Pasangan Usia Subur (PUS). Sampel penelitian diperoleh dari sampel Pasangan Besar sampel keluarga pada survei tersebut sebanyak 69.515 orang dan yang berhasil diwawancarai sebanyak 99\%, yaitu keluarga 
terdiri dari pasangan usia subur yang berusia 15-49 tahun. Variabel yang dianalisis dalam penelitian ini meliputi pengetahuan, keterpaparan sumber informasi, pemakaian kontrasepsi menurut umur, latar belakang, dan pemilihan alat/cara KB berdasarkan informasi yang diterima.

\section{HASIL DAN PEMBAHASAN}

Hasil penelitian ini diuraikan berdasarkan variabel yang dianalisis yang meliputi pengetahuan, keterpaparan sumber informasi, pemakaian kontrasepsi menurut umur, latar belakang, dan pemilihan alat /cara KB berdasarkan informasi yang diterima.

\section{Pengetahuan Mengenai Alat /Cara KB}

Pengetahuan mengenai alat/cara KB merupakan hal yang penting dimiliki sebagai bahan pertimbangan sebelum menggunakannya. Informasi mengenai pengetahuan dan pemakaian alat/cara KB diperlukan untuk mengukur keberhasilan Program Kependudukan, Keluarga Berencana dan Pembangunan Keluarga (KKBPK) (BKKBN, 2018)

Informasi yang dkumpulkan mencakup alat/cara KB modern dan tradisional. Alat/cara KB modern terdiri dari metode operasi wanita (MOW) atau strilisasi wanita, metode operasi pria (MOP) atau sterilisasi pria, pil, IUD, suntik KB, susuk KB, kondom, diafragma, metode amenore laktasi (MAL), dan kontrasepsi darurat alat/cara KB tradisional terdiri dari gelang manik, pantang berkala, senggama terputus, dan alat/cara KB tradisional lainnya.

Hasil survei indikator RPJMN tahun 2018 khususnya pengetahuan mengenai alat/cara KB didapatkan gambaran data seperti yang tertera dalam Tabel 1.

Tabel 1. Persentase Wanita Berstatus Menikah/Hidup Bersama dengan Pasangan yang Mengetahui Paling Sedikit Satu Alat/Cara KB, Indonesia 2018

\begin{tabular}{lc}
\hline \multicolumn{1}{c}{ Metode } & Wanita berstatus menikah/hidup bersama dengan pasangan \\
\multicolumn{1}{c}{ Alat/cara KB modern } & \\
\hline Sterilisasi wanita/tubektomi & 99,8 \\
Sterilisasi pria/vesektomi & 74,6 \\
Susuk KB/Implan & 39,4 \\
IUD/spiral & 95,8 \\
Suntikan & 88,8 \\
PIL & 99,5 \\
Kontrasepsi darurat & 99,0 \\
Kondom pria & 12,6 \\
Kondom wanita & 92,2 \\
Intravag/diafragma & 11,7 \\
MAL & 6,6 \\
\hline Alat/cara KB tradisional & \\
\hline Gelang manik & 6,6 \\
Pantang berkala & 59,0 \\
Senggama terputus & 64,6 \\
Lainnya & 38,3 \\
\hline
\end{tabular}

Tabel 1 menggambarkan bahwa pengetahuan wanita berstatus menikah/hidup bersama dengan pasangan menggunakan alat/cara KB modern sebesar 99,8\%. Pengetahuan mengenai metode kontrasepsi sterilisasi wanita/tubektomi $74,6 \%$, sterilisasi pria/vasektomi $39,4 \%$, susuk KB/Implan 95,8\%, IUD 88,8\%, suntikan 99,5\%, pil $99,0 \%$, kontrasepsi darurat $12,6 \%$, kondom pria $92,2 \%$, kondom wanita $11,7 \%$, intrafag/diafragma 6,6 \%, MAL $34,9 \%$.

Alat/cara KB tradisional sebesar 82,9\%, gelang manik 6,6\%, pantang berkala 59,0\%, senggama terputus $64,6 \%$, lainnya $38,3 \%$. Rata rata alat /cara $\mathrm{KB}$ yang diketahui $8,2 \%$, jumlah peserta keseluruhan 47.053 orang. Pengetahuan alat/cara KB yang terbesar pada alat/cara KB moden sebesar 99,8\% yaitu alat/cara KB suntikan 99,0\%. Sedangkan terendah yaitu pengetahuan alat/cara KB diafragma dan gelang manik sebesar 6,6\%,. 


\section{Keterpaparan Sumber Informasi KB dari Media dan Petugas}

Kegiatan komunikasi, informasi dan edukasi (KIE) KB di Indonesia merupakan kegiatan penerangan dan sosialisasi program KB melalui berbagai media. Media memiliki peranan penting dalam mensosialisasikan keluarga berencana. Media massa adalah media yang dapat menjangkau khalayak yang lebih sedikit bila dibandingkan dengan media massa.

Media luar ruang mencakup pamflet, leaflet/brosur, flipchart/lembar balik, poster, spanduk, billboard, pameran, mupen KB, dan lainnya. Kontak dengan petugas lapangan KB (PLKB) dan petugas kesehatan lainnya serta dengan guru, tokoh agama, tokoh masyarakat, dokter, bidan/perawat, perangkat desa serta PPKBD/Sub PPKBD juga sangat berperan dalam penyebaran informasi dan sosialisasi program Keluarga Berencana.

Tabel 2. Persentase Wanita Kawin Usia 15-49 Tahun yang Mengetahui Informasi Tentang KB dari Media Informasi, Indonesia 2018

\begin{tabular}{lccc}
\hline Karakteristik Latar Belakang & $\begin{array}{c}\text { Pamflet/leaflet } \\
\text { /brosur }\end{array}$ & Spanduk & $\begin{array}{c}\text { Wanita kawin yang } \\
\text { mendengar tentang KB }\end{array}$ \\
\hline Umur & & & \\
\hline $15-19$ & 12,3 & 44,0 & 598 \\
$20-24$ & 17,0 & 49,2 & 3.773 \\
$25-29$ & 18,3 & 51,4 & 7.279 \\
$30-34$ & 18,8 & 50,0 & 8.580 \\
$35-39$ & 17,5 & 50,3 & 9.132 \\
$40-44$ & 16,2 & 47,4 & 6.307 \\
$45-49$ & 15,6 & 46,5 & \\
\hline Daerah tempat tinggal & & & 21.911 \\
\hline Perkotaan & 20,0 & 52,3 & \\
Perdesaan & 14,5 & 46,0 & 526 \\
\hline Pendidikan terakhir & & & 14.581 \\
\hline Tidak sekolah & 5,6 & 31,5 & 10.965 \\
SD & 9,9 & 39,2 & 13.450 \\
SLTP & 16,6 & 50,3 & 3.554 \\
SLTA & 20,6 & 54,9 & \\
D1/D2/D3/Akademi & 32,8 & 60,1 & \\
Perguruan Tinggi & 31,9 & 62,5 & \\
\hline
\end{tabular}

Tabel 2 menjelaskan bahwa wanita kawin usia 15-49 tahun yang mengetahui informasi tentang KB dari media pamflet terbanyak direntang umur 30-34 tahun (18,8\%). Media informasi melalui spanduk terbanyak diakses oleh umur 25-29 tahun $(51,4 \%)$.

Tabel 3. Persentase Wanita Kawin Usia 15-49 Tahun yang Mengetahui Informasi Tentang KB dari Petugas, Indonesia 2018

\begin{tabular}{lcccc}
\hline $\begin{array}{c}\text { Karakteristik Latar } \\
\text { belakang }\end{array}$ & $\begin{array}{c}\text { PLKB } \\
\text { /Penyuluh KB }\end{array}$ & Bidan & $\begin{array}{c}\text { Tetangga/teman } \\
\text { /saudara }\end{array}$ & $\begin{array}{c}\text { Wanita kawin } \\
\text { yang mendengar } \\
\text { tentang KB }\end{array}$ \\
\hline Umur & & & & \\
\hline $15-19$ & 15,8 & 73,8 & 72,6 & 598 \\
$20-24$ & 22,3 & 76,8 & 69,0 & 3.773 \\
$25-29$ & 25,9 & 77,9 & 66,0 & 7.279 \\
$30-34$ & 28,3 & 77,8 & 66,5 & 8.580 \\
$35-39$ & 29,3 & 76,1 & 64,3 & 9.132 \\
$40-44$ & 30,1 & 74,3 & 65,7 & 8.307 \\
$45-49$ & 29,7 & 71,3 & 64,9 & \\
\hline Daerah tempat tinggal & & & & \\
\hline Perkotaan & 25,0 & 71,9 & 66,797 \\
Perdesaan & 30,9 & 79,3 & 64,9 & \\
\hline Pendidikan terakhir & & & & \\
\hline Tidak sekolah & 18,7 & 70,7 & 63,1 & \\
SD & 25,9 & 77,0 & 63,8 & 14.551 \\
SLTP & 27,4 & 78,4 & 66,3 & 10.965 \\
SLTA & 28,8 & 73,5 & 67,9 & 13.450 \\
\hline
\end{tabular}




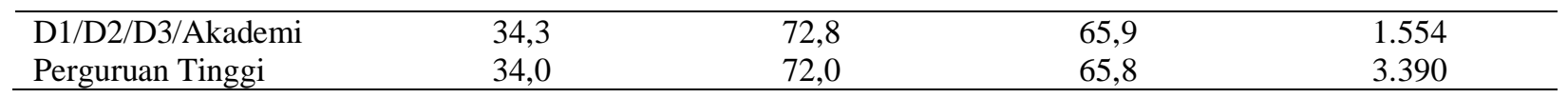

Pada tabel 3 menjelaskan bahwa media informasi yang didapatkan dari petugas PLKB/ Penyuluh KB terbanyak direntang umur 40-44 tahun (30,1\%), daerah tempat tinggal di perdesaan (30,9), dan pendidikan terakhir D1/D2/D3/Akademik (34,3\%). Media informasi yang didapatkan dari petugas Bidan terbanyak direntang umur 2529 (77,9\%), tempat tinggal di perdesaan (79,3), dan pendidikan terakhir jenjang SLTP $(78,4 \%)$. Media informasi yang didapatkan dari tetangga /teman /saudara terbanyak direntang umur 15-19 tahun (72,6\%), tempat tinggal di perkotaan $(66,9 \%)$, dan pendidikan terakhir jenjang SLTA $(67,9 \%)$.

\section{Keterpaparan sumber informasi KB dari institusi}

Informasi dapat juga diperoleh dari institusi masyarakat mencakup melalui pendidikan formal, pendidikan non-formal, organisasi kemasyarakatan.

Tabel 4. Persentase Wanita Kawin Usia 15-49 Tahun yang Mengetahui Informasi Tentang KB dari Institusi, Indonesia 2018

\begin{tabular}{lcccc}
\hline $\begin{array}{c}\text { Karakteristik Latar } \\
\text { belakang }\end{array}$ & $\begin{array}{c}\text { Pendidikan } \\
\text { formal }\end{array}$ & $\begin{array}{c}\text { Pendidikan non } \\
\text { formal }\end{array}$ & $\begin{array}{c}\text { Organisasi } \\
\text { kemasyarakatan }\end{array}$ & $\begin{array}{c}\text { Wanita kawin } \\
\text { yang mendengar } \\
\text { tentang KB }\end{array}$ \\
\hline Umur & & & & \\
\hline $15-19$ & 16,8 & 1,4 & 40,6 & 598 \\
$20-24$ & 22,5 & 2,8 & 54,4 & 3.773 \\
$25-29$ & 21,3 & 3,0 & 57,1 & 7.279 \\
$30-34$ & 20,7 & 3,2 & 59,5 & 9.580 \\
$35-39$ & 17,1 & 2,6 & 58,4 & 8.132 \\
$40-44$ & 16,4 & 2,4 & 56,5 & 6.797 \\
$45-49$ & 14,6 & 2,9 & 57,1 & \\
\hline Daerah tempat tinggal & & & & 21.911 \\
\hline Perkotaan & 21,5 & 3,2 & 55,4 & \\
Perdesaan & 15,4 & 2,4 & 59,1 & 526 \\
Pendidikan terakhir & & & & 14.581 \\
\hline Tidak sekolah & 5,6 & 1,0 & 52,2 & 10.965 \\
SD & 7,7 & 1,7 & 56,9 & 13.450 \\
SLTP & 15,3 & 2,0 & 59,3 & 3.554 \\
SLTA & 24,5 & 3,2 & 56,8 & \\
D1/D2/D3/Akademi & 41,9 & 8,0 & 56,9 & \\
Perguruan Tinggi & 42,0 & 6,6 & 54,9 & \\
\hline
\end{tabular}

Pada tabel 4 menjelaskan bahwa bahwa media informasi yang didapatkan dari pendidikan formal terbanyak diakses umur 20-24 tahun (22,5\%), daerah tempat tinggal di perkotaan (21,5\%), dan pendidikan terakhir PT $(42,0 \%)$. Media informasi yang didapatkan dari pendidikan non formal terbanyak diakses umur 30-34 (3,2\%), tempat tinggal di perkotaan (3,2\%), dan pendidikan terakhir jenjang D1/D2/D3/Akademik (8,0\%). Media informasi yang didapatkan dari organisasi kemasyarakatan terbanyak diakses umur 30-34 tahun (59,5\%), tempat tinggal di perdesaan $(9,1 \%)$, dan pendidikan terakhir jenjang SLTP $(59,3 \%)$.

\section{Pemakaian Kontrasepsi Saat Ini}

Pemakaian kontrasepsi saat ini di peroleh dari distribusi persentase umur dengan suatu alat /cara modern.

Tabel 5. Persentase Wanita Kawin Usia 15-49 Tahun Menurut Alat/Cara KB yang Dipakai Menurut Umur, Daerah Tempat Tinggal, dan Pendidikan Terakhir, Indonesia 2018

\begin{tabular}{lcccc}
\hline $\begin{array}{c}\text { Karakteristik Latar } \\
\text { Belakang }\end{array}$ & IUD & Pil & Kondom Pria & $\begin{array}{c}\text { Senggama } \\
\text { Terputus }\end{array}$ \\
\hline Umur & & & & \\
\hline $15-19$ & 1,5 & 7,2 & 0,0 & 2,3 \\
$20-24$ & 2,9 & 8,0 & 1,4 & 1,4 \\
$25-29$ & 3,5 & 8,9 & 1,0 & 1,7
\end{tabular}




\begin{tabular}{lcccc}
$30-34$ & 4,9 & 11,2 & 2,2 & 2,3 \\
$35-39$ & 5,7 & 13,1 & 1,6 & 1,6 \\
$40-44$ & 5,2 & 13,9 & 2,2 & 2,1 \\
$45-49$ & 4,7 & 12,2 & 1,5 & 2,4 \\
\hline Daerah tempat tinggal & & & & 1,3 \\
\hline Perkotaan & 6,2 & 11,0 & 2,4 & 0,3 \\
Perdesaan & 3,2 & 12,0 & 1,0 & 0,9 \\
\hline Pendidikan terakhir & & 6,6 & 0,1 & 2,0 \\
\hline Tidak sekolah & 1,3 & 14,0 & 0,6 & 2,6 \\
SD & 2,5 & 12,6 & 1,6 & 3,4 \\
SLTP & 3,5 & 10,0 & 2,3 & 3,0 \\
SLTA & 6,1 & 6,4 & 4,9 & \\
D1/D2/D3/Akademi & 9,5 & 5,8 & 3,4 & \\
Perguruan Tinggi & 9,5 & & & \\
\hline
\end{tabular}

Pada tabel 5 menjelaskan bahwa alat/cara KB IUD yang dipakai menurut umur terbanyak pada rentang 3539 (5,70\%), daerah tempat tinggal di perkotaan (6,20\%), dan pendidikan terakhir jenjang PT $(9,5)$. Alat/cara KB Pil yang dipakai menurut umur terbanyak pada rentang 40-44 tahun (13,9\%), daerah tempat tinggal di perdesaan $(12,0 \%)$, pendidikan terakhir jenjang SD $(14,0 \%)$. Alat/cara KB Kondom pria yang dipakai menurut umur terbanyak pada rentang 40-44 tahun (2,20\%), daerah tempat tinggal di perkotaan $(2,4 \%)$, pendidikan terakhir jenjang D1/D2/D3/Akademi (4,9\%). Alat/cara KB Senggama Terputus yang dipakai menurut umur terbanyak pada rentang 15-19 tahun (2,30\%), daerah tempat tinggal di perkotaan (2,4\%), pendidikan terakhir jenjang D1/D2/D3/Akademi $(3,40 \%)$.

Tren Pemakaian Alat/Cara KB

Tabel 6. Persentase Tren Pemakaian wanita alat/cara KB tertentu di antara wanita kawin 15-49 tahun, Indonesia 1991-2018

\begin{tabular}{|c|c|c|c|c|c|c|c|c|c|}
\hline $\begin{array}{c}\text { Alat/cara } \\
\text { KB }\end{array}$ & $\begin{array}{c}\text { SDKI } \\
1991\end{array}$ & $\begin{array}{c}\text { SDKI } \\
1994\end{array}$ & $\begin{array}{l}\text { SDKI } \\
1997\end{array}$ & $\begin{array}{l}\text { SDKI } \\
2002 / \\
2003 \\
\end{array}$ & $\begin{array}{c}\text { SDKI } \\
2007\end{array}$ & $\begin{array}{c}\text { SDKI } \\
2012\end{array}$ & $\begin{array}{c}\text { SDKI } \\
2017\end{array}$ & $\begin{array}{c}\text { RPJMN } \\
2017\end{array}$ & $\begin{array}{c}\text { SKAP } \\
2018\end{array}$ \\
\hline PIL & 14,8 & 17,1 & 15,4 & 13,2 & 13,2 & 13,6 & 12,1 & 12,3 & 11,5 \\
\hline IUD & 13,3 & 10,3 & 8,1 & 6,2 & 3,9 & 3,9 & 4,7 & 3,6 & 4,6 \\
\hline Suntik & 11,7 & 15,2 & 21,1 & 27,8 & 31,9 & 31,9 & 29,0 & 31,7 & 30,5 \\
\hline Kondom & 0,8 & 0,9 & 0,7 & 0,9 & 1,3 & 1,8 & 2,5 & 1,2 & 1,7 \\
\hline Susuk & 3,1 & 4,9 & 6 & 4,3 & 2,8 & 3,3 & 4,7 & 5,7 & 5 \\
\hline $\begin{array}{l}\text { Sterilisasi } \\
\text { wanita }\end{array}$ & 2,7 & 3,1 & 3 & 3,7 & 3 & 3,2 & 3,8 & 3 & 3,3 \\
\hline $\begin{array}{l}\text { Sterilisasi } \\
\text { pria }\end{array}$ & 0,6 & 0,7 & 0,4 & 0,4 & 0,2 & 0,2 & 0,2 & 0,1 & 0,1 \\
\hline $\begin{array}{l}\text { Pantang } \\
\text { berkala }\end{array}$ & 1,1 & 1,1 & 1,1 & 1,6 & 1,5 & 1,3 & 1,9 & 0,9 & 1,3 \\
\hline $\begin{array}{l}\text { Senggama } \\
\text { terputus }\end{array}$ & 0,7 & 0,8 & 0,8 & 1,5 & 2,1 & 2,3 & 4,2 & 1,2 & 1,9 \\
\hline Lainnya & 0,9 & 0,8 & 0,8 & 0,5 & 0,4 & 0,4 & 0,3 & 0,2 & 0,2 \\
\hline
\end{tabular}

Tabel 6 menunjukkan bahwa penggunaan alat/cara KB Pil dari Laporan SDKI 1991 sampai SKAP 2018 cenderung menurun. Tahun 1991 ke 1994 naik dengan selisih persentase 2,3\%. penggunaan alat/cara KB IUD cenderung menurun, dan hanya mengalami kenaikan di tahun 2017 sampai 2018. Penggunaan alat/cara KB suntik mengalami tren yang cenderungan naik. Penggunaan alat/cara kondom susuk cenderung trennya naik turun, persentase $2,5 \%$ di tahun 2017.

\section{PEMBAHASAN}

\section{Pengetahuan Mengenai Alat /Cara KB}

Berbagai alat/cara KB modern sangat penting diketahui oleh setiap wanita. Wanita diharapkan mengetahui berbagai kelebihan metode KB yang mencakup efektivitas dan kepraktisan penggunaannya. Manfaat wanita mengetahui berbagai alat/cara KB modern adalah agar wanita dapat memilih dan memutuskan alat/cara KB yang 
tepat bagi dirinya dan pasangannya. Pengetahuan jenis alat/cara KB secara umum terdiri atas pengetahuan jenis alat/cara KB modern dan pengetahuan jenis alat/cara KB tradisional (BKKBN, 2018).

Pengetahuan tentang alat/cara KB sudah umum di Indonesia. Sembilan puluh sembilan persen wanita mengetahui paling sedikit satu jenis alat/cara KB, sedangkan untuk wanita kawin hampir 100 persen mengetahui paling sedikit satu jenis alat/cara KB. Tetapi untuk wanita yang belum kawin mengetahui satu alat/cara KB sebesar 96 persen. Rata-rata alat/cara KB yang diketahui oleh semua wanita adalah 7,8 alat/cara KB, sedangkan pada wanita kawin 8,2 alat/cara KB dan wanita yang belum kawin tahu 6 alat/cara KB.

Lebih dari 90 persen wanita kawin telah mengetahui kontrasepsi modern pil, suntik, kondom pria dan implant, tetapi untuk metoda operasi wanita (MOW) sebanyak 75 persen dan metode operasi pria (MOP) masih relatif rendah yaitu 39 persen. Pengetahuan cara KB metode amenorhea laktasi (MAL) masih rendah yaitu 35 persen.Untuk jenis kontrasepsi tradisional, seperti pantang berkala dan senggama putus diketahui wanita berstatus kawin/hidup bersama sekitar 60 persen (BKKBN, 2018).

Hal ini sejalan dengan penelitian Mahmudah dan Indrawati (2015) yaitu adanya hubungan pengetahuan dengan pemilihan MKJP. Responden dengan pengetahuan cukup dan kurang memliki peluang lebih besar memilih metode kontrasepsi non MKJP. Responden dengan pengetahuan baik akan memilih metode kontrasepsi MKJP. Hal tersebut di karenakan tingkat wawasan yang lebih luas memudahkan untuk menerima inovasi dan pengambilan keputusan.

Hasil SKAP 2018 dibandingkan dengan hasil Survei Indikator Kinerja Program KKBPK RPJMN 2017 menunjukkan bahwa pengetahuan pasangan usia subur terhadap semua jenis alat/cara KB modern sedikit meningkat dari 17 persen menjadi 18 persen (BKKBN, 2018). Hal ini sejalan dengan penelitian (Anggraini, 2015), bahwa pengetahuan responden tentang program $\mathrm{KB}$ cukup. Responden juga mengetahui pandangan/pendapat tentang program KB masa kini dan alat-alat kontrasepsi yang digunakan dalam program KB.

Hasil dari penelitian lain Setiasih, Widjanarko dan Istiarti (2016), yaitu pengetahuan berpengaruh dalam pengambilan keputusan dan memiliki wawasan yang luas sehingga memudahkan dalam menerima inovasi baru. Pencapaian nasional tentang pengetahuan pasangan usia subur terhadap semua alat/cara/metode kontrasepsi modern (delapan jenis alat/cara/metode KB modern) sebesar 18 persen, maka target yang ditetapkan RPJMN 2015-2019 sebesar 31 persen pada 2018 belum dicapai. Namun untuk pengetahuan tujuh metode kontrasepsi modern (mencakup sterilisasi wanita, sterilisasi pria, susuk KB, IUD, pil KB, suntik KB, dan kondom pria) sudah mencapai 47 persen (BKKBN, 2018).

Pengetahuan pasangan sangatlah penting untuk memutuskan pemilihan alat/cara KB. Pada penelitian (Imbarwati, 2010), Faktor pengetahuan suami sebagai pasangan dari peserta KB juga berkontribusi cukup besar sebagai pendukung sekaligus penganjur istri dalam menjatuhkan pilihan kontrasepsi. Suami yang memiliki pengetahuan cukup tentang IUD akan cenderung menganjurkan dan mengijinkan istrinya menggunakan alat kontrasepsi jangka panjang tersebut.

\section{Keterpaparan sumber informasi KB dari media dan petugas}

Responden di perkotaan lebih banyak terpapar informasi tentang KB dari sumber media apapun dibandingkan yang tinggal di perdesaan. Umumnya perbedaan informasi dari berbagai jenis media yang didapat oleh responden di daerah perkotaan dan perdesaan selisihnya antara 2-5 persen.

Sumber informasi dari jenis media banner dan website masing-masing perbedaannya antar wilayah kota dan desa mencapai sembilan persen dan 13 persen. Informasi dari sumber radio hampir tidak ada perbedaan antara perkotaan dengan perdesaan yakni masing-masing persentasenya sembilan dan delapan persen. Penelitian dari Herawati (2014), bahwa responden lebih banyak menerima informasi KB dari tetangga (35 \%) daripada dari puskesmas (22,5\%). Penelitian dari (Purwaningsih, 2012), menyatakan bahwa PLKB/PKB merupakan ujung tombak program KB. Melalui PLKB/PKB program KB disampaikan kepada masyarakat desa.

Proporsi wanita berstatus kawin usia 15-49 tahun yang terpapar pesan melalui sumber media massa dan media luar ruang menunjukkan hubungan yang positif dengan

tingkat pendidikan dan status kekayaan. Pendidikan yang tinggi maka semakin tinggi kuintil kekayaan. Kecenderungan semakin besar persentasenya yang mengetahui informasi tentang KB dari berbagai jenis media. Jika dilihat dari kelompok umur, sumber informasi KB pada sebagian media tampak pola seperti huruf "U" terbalik, kelompok umur 25-39 tahun persentasenya relatif lebih tinggi dibandingkan dengan kelompok umur lebih muda dan lebih tua, khususnya untuk jenis media koran, spanduk, pamflet, lembar balik, spanduk, banner, dan internet (BKKBN, 2018).

Hasil penelitian lain Sopacua (2011) menyebutkan bahwa informasi KB melalui komunikasi personal lebih baik daripada media massa. Proses pemberi informasi dan penerima informasi dalam hubungan interpersonal, yaitu pertemanan, keluarga dan petugas kesehatan. Komunikasi memegang peranan penting dalam penyampaian 
pesan alat/cara metode KB dalam bentuk percakapan maupun wawancara. Penelitian (Zuhriyah, Indarjo dan Bambang Budi Raharjo, 2017), menyatakan bahwa pembetukan program kampung KB yang telah berjalan satu tahun terjadi peningkatan kualitas dalam memilih alat kontasepsi.

Penelitian lain dari Munandar (2017) menyatakan bahwa pemberian informasi bahwa sebesar 76,6\% responden yang memperoleh informasi menyatakan tidak setuju terhadap KB. Responden yang tidak memperoleh informasi KB sebesar 23,4\% setuju terhadap KB. Responden yang tidak setuju terhadap KB mengatakan kurangnya informasi tentang KB menyebabkan responden yang tidak mengetahui keuntungan dan kerugian jika ikut KB.

\section{Keterpaparan sumber informasi KB dari institusi}

Wanita kawin usia 15-49 tahun paling banyak memperoleh informasi tentang KB dari organisasi kemasyarakatan (57 persen), diikuti kelompok masyarakat dan pendidikan formal (masing-masing 20\% dan 18\%). Sedangkan informasi tentang KB dari institusi kelompok kegiatan (poktan) hanya 8\% dari institusi pendidikan nonformal hanya tiga persen. Sebesar $29 \%$ wanita tidak mendengar informasi tentang KB dari satupun sumber informasi institusi.

Sumber informasi KB dari institusi antara perdesaan dan perkotaan tidak jauh erbeda, hanya selisih 2-5\% kecuali keterpaparan terhadap pendidikan formal. Daerah perkotaan sumber informasi KB dari pendidikan formal jalur lebih tinggi daripada di perdesaan. Sebaliknya sumber informasi KB dari organisasi kemasyarakatan, kelompok masyarakat dan kelompok kegiatan, lebih tinggi di perdesaan daripada di perkotaan (BKKBN, 2018).

Menurut penelitian dari Sukardi (2018), media informasi terhadap responden bisa dilakukan dengan KIE kelompok. Kegiatan KIE kelompok antara lain Kegiatan Posyandu, Rapat pertemuan di kantor desa, Kegiatan Poktan BKB, BKR, BKL, dan UPPKS, serta Rakor desa dan kecamatan. Hal ini juga sejalan dengan penelitian dari Oktariyanto (2016), pemberian informasi data Faskes yang bekerja sama dengan BPJS Kesehatan dan data Faskes yang terdaftar dalam K/0/KB-BKKBN belum baik. Penelitian dari Oesman (2017), juga menyatakan pemanfaatan kartu BPJS Kesehatan untuk pelayanan KB terlihat masih sangat rendah, yaitu 11,6 persen, dengan kategori PBI maupun non PBI.

\section{Pemilihan Metode Kontrasepsi Paling Banyak di Provinsi Jawa Timur}

Berdasarkan tabel 5 diketahui bahwa alat kontrasepsi yang paling banya dipilih dan digunakan oleh wanita kawin usia 15-49 tahun adalah suntikan 3 bulanan. Data hasil SKAP 2018 menunjukkan bahwa lebih dari $50 \%$ wanita kawin usia 15-49 tahun menggunakan metode KB tersebut.

Metode KB suntikan 3 bulanan memiliki berbagai kelebihan dan kekurangan. Kelebihan dari KB suntikan 3 bulan yaitu praktis, masa kerjanya cukup lama dibandingkan metode lain, angka kegagalan kurang dari 0,1\% per tahun, tidak, mengganggu kelancaran ASI dan tidak menimbulkan ketergantungan.

Penggunaan alat kontrasepsi yang paling banyak di minati oleh peserta KB di Provinsi Jawa Timur memiliki keterbatasan yang harus diperhatikan. Gangguan tersebut yaitu menstruasi, amenorea, spotting, keputihan, peningkatan berat badan, gangguan mual muntah Rahayu et al. (2017). Penelitian Kurniawan et al. (2019), yang paling penting dari pemilihan KB yaitu seseorang dalam memakai sesuatu akan memilih yang ekonomis dan efisien. Pemilihan alat/cara kontrasepsi yang mudah dan murah akan banyak yang lebih berminat. Penelitian Samtyaningsih et al. (2018), menyatakan bahwa sebagian besar responden yang tidak ikut dalam program KB, mereka adalah pasangan yang tidak menggunakan kontrasepsi dan memilih alat kontrasepsi kondom sebagai pencegahan kehamilan.

\section{KESIMPULAN Simpulan}

Pengetahuan wanita kawin usia 15-49 tahun yang tinggi maka semakin teliti dalam pemilihan metode kontrasepsi yang akan digunakannya. Semakin pengetahuan wanita tersebut baik kemungkinan untuk menggunakan KB lebih besar. Wanita kawin usia 15-49 tahun yang berpendidikan tinggi menunjukkan semakin banyak terpapar media informasi. Wanita yang terpapar media informasi lebih banyak menunjukkan memiliki wawasan yang lebih luas dalam menentukan metode kontrasepsi.

Metode kontrasepsi yang paling banyak digunakan oleh wanita kawin usia 15-49 tahun adalah KB suntikan 3 bulan. eserta KB yang menggunakan KB suntik 3 bulan lebih dari 50\% di Provinsi Jawa Timur Tahun 2018. Akseptor KB yang menganggap biaya harus ditanggung untuk mendapatkan pelayanan kontrasepsi tidak mahal mempunyai kemungkinan 0,078 lebih besar untuk memilih kontrasepsi non MKJP.

Saran

Masukan yang dapat diberikan oleh Perwailan BKKBN Provinsi Jawa Timur adalah bahwa alat kontrasepsi yang paling banyak diminati adalah suntikan 3 bulan maka dari itu persediaan alkon tersebut diharapkan jangan 
sampai kosong. Metode kontrasepsi yang lain kurang banyak diminati sehingga penggunanya jumlahnya relatif kecil.

Perwakilan BKKBN Provinsi Jawa Timur hendaknya lebih menggalakkan penggunaan metode kontrasepsi lain. Hal tersebut bertujuan mengubah mindset wanita usia subur bahwa ada beberapa metode KB lain lain yang menyesuaikan kebutuhan WUS tersebut yang dapat dilihat dari masa kerjanya/durasinya, efektifitasnya dan biaya yang dikeluarkan.

\section{ACKNOWLEDGEMENT}

Penulis mengucapkan terima kasih kepada seluruh staf pengajar Fakultas Kesehatan Masyarakat Universitas Airlangga atas bimbingan dan bantuan selama pelaksanaan penelitian ini dan para pasien yang telah bersedia menjadi responden.

\section{DAFTAR PUSTAKA}

Anggraini, I. (2015) 'Sikap pasangan usia subur terhadap drop out peserta program keluarga berencana (KB)', Jurnal Ilmu Administrasi Negara Universitas Jember, I, pp. 1-13.

BKKBN (2018) Survei Kinerja dan Program KKBPK. Edited by L. A. Kasmiyati, Flourisa Julian, Endah Winarni, Maria Anggraeni. Jakarta: Badan Kependudukan dan Keluarga Berencana Nasional.

Herawati, A. F. (2014) 'Hubungan antara Penerimaan dan Pemahaman Informasi KB dalam Pengendalian Kelahiran Keluarga Nelayan Pesisir Kecamatan Banawa Kabupaten Donggala', Jurnal ACADEMICA Fisip Untad, 6(1), pp. 1186-1194.

Herman Kurniawan, Rasyika Nurul, R. H. (2019) 'Perilaku Akseptor Dalam Memilih Metode Kontrasepsi Jangka Panjang (Mkjp) Di Poskesdes Anuta Singgani Kecamatan Mantikulore Kota Palu’, Jurnal Preventif, 53(9), pp. 1689-1699. doi: 10.1017/CBO9781107415324.004.

Imbarwati (2010) 'Penggunaan Alat Kontrasepsi KB IUD pada Peserta KB non IUD di Kecamatan Pedurungan Kota Semarang', Jurnal Promosi Kesehatan Indonesia, 5(2), pp. 164-175. doi: 10.14710/jpki.5.2.164-175.

Mahmudah, L. T. N. and Indrawati, F. (2015) 'Analisis Faktor yang Berhubungan dengan Pemilihan Metode Kontrasepsi Jangka Panjang (MKJP) pada Akseptor KB Wanita di Kecamatan Banyubiru Kabupaten Semarang', Unnes Journal of Public Health, 4(3), pp. 76-85.

Munandar, B. (2017) 'Peran Informasi Keluarga Berencana pada Persepsi dalam Praktik Keluarga Berencana', Jurnal Swarnabhumi, 2(1), pp. 50-58.

Oesman, H. (2017) 'Pola Pemakaian Kontrasepsi Dan Pemanfaatan Kartu Badan Penyelengara Jaminan Sosial (Bpjs) Kesehatan Dalam Pelayanan Keluarga Berencana di Indonesia', Jurnal Kesehatan Reproduksi, 8(1), pp. 15-29. doi: 10.22435/kespro.v8i1.6386.15-29.

Oktariyanto, O. (2016) 'Penyelenggaraan Pelayanan Keluarga Berencana dalam Jaminan Kesehatan Nasional', Jurnal Ilmu Keluarga dan Konsumen, 9(2), pp. 77-88. doi: 10.24156/jikk.2016.9.2.77.

Purwaningsih, S. S. (2012) 'Desentralisasi Program Keluarga Berencana: Tantangandanpersoalan Kasus Provinsi Kalimantan Barat the Decentralization of the Family Planning Program: Challanges and Issues ', Jurnal Kependudukan Indonesia, VII(2), pp. 109-125.

Rahayu, T. B. and Wijanarko, N. (2017) 'Efek Samping Akseptor KB Suntik Depo Medroksi Progesterone Acetat (DMPA) Setelah 2 Tahun Pemakaian', Jurnal Kesehatan 'Samodra Ilmu', 8(1), pp. 32-38.

Samtyaningsih, D. and Ibaadillah, A. A. (2018) 'Hubungan Pengetahuan Suami Tentang Alat Program Keluarga Berencana Di Perumahan Sumberingin Permai Kabupaten Trenggalek', Conference of Innovation and Application of Science and Technology (CIASTECH), (September), pp. 376-381.

Setiasih, S., Widjanarko, B. and Istiarti, T. (2016) 'Analisis Faktor-faktor yang Mempengaruhi Pemilihan Metode Kontrasepsi Jangka Panjang (MKIP) pada Wanita Pasangan Usia Subur (PUS) di Kabupaten Kendal Tahun 2013', Jurnal Promosi Kesehatan Indonesia, 11(2), pp. 32-46.

Sopacua, Y. (2011) 'Pengaruh Informasi Terhadap Adopsi Alat Kb Di Kalangan Ibu Rumah Tangga Pedagang Kaki Lima Di Desa Batu Merah Kota Ambon’, Jurnal Komunikasi KAREBA, 1(2), pp. 183-189.

Sukardi (2018) 'Audit Komunikasi Program Komunikasi, Informasi dan Edukasi (KIE) Keluarga Berencana pada Perwakilan BKKBN Provinsi Sulawesi Barat', Jurnal Komunikasi KAREBA, 7(2), pp. 264-274.

Zuhriyah, A., Indarjo, S. and Bambang Budi Raharjo (2017) 'Higeia Journal of Public Health', Higeia Journal of Public Health Research and Development, 1(3), pp. 84-94. 